\title{
Addition of Waste Glass to Self-Compacted Concrete: Critical Review
}

\author{
Mahmoud B.A. Alhasanat ${ }^{1}$, Arabi N. Al Qadi ${ }^{1}$, Salah Al-Thyabat ${ }^{2}$, Madhar Haddad ${ }^{3} \&$ Batool G. Nofal $^{1}$ \\ ${ }^{1}$ Department of Civil Engineering, AL Hussein Bin Talal University, Ma'an, Jordan \\ ${ }^{2}$ Department of Mining Engineering, AL Hussein Bin Talal University, Ma'an, Jordan \\ ${ }^{3}$ Department of Architectural Engineering, United Arab Emirates University, Al Ain, UAE \\ Correspondence: Mahmoud B. Alhasanat, Department of civil engineering, AL Hussein Bin Talal University, \\ Ma'an, Jordan. E-mail: 20petra07@gmail.com
}

Received: May 16, 2016

doi:10.5539/mas.v10n11p1
Accepted: June 10, 2016

Online Published: July 11, 2016

URL: http://dx.doi.org/10.5539/mas.v10n11p1

\begin{abstract}
Utilization of waste glass at optimum amounts in concrete production not only provides significant environmental benefits such as reducing carbon dioxide emissions generated during the production process of cement but also enhances performance of the concrete and cement. The aim of this work was to review the effect of addition of waste glass on cement and concrete. The review showed that addition of glass powder enhances the compressive strength properties of the concrete product while using waste glass as aggregate showed that the slump flow increased with the increase of recycled glass content. On the other hand, the compressive strength, splitting tensile strength and flexural strength of the concrete were decreased with the increase in the recycled glass content.
\end{abstract}

Keywords: waste glass, self-compacted concrete, fiber, cement

\section{Introduction}

Nowadays, cement and glass industries face serious problems such as increasing environmental pressure resulting from high greenhouse gases emissions and overcapacity (Ali et al., 2011; Mikulčić et al. 2013). Due to non-biodegradable nature of waste glass, discarding it to landfill is not an environmental friendly practice (Cassar et al., 2012; Liu, 2011). However, waste glass chemical composition and pozzolanic properties encourage its use in the cement and concrete industries providing practical and an environmental friendly solution for both of glass and cement industries (Dhirendra et al., 2012; Khmiri et al., 2012).

In this review we will shed some light on the latest practices of using waste glass in cement and concrete industry including optimum ratio between waste glass and cement/concrete, and the effect of the glass properties on the performance and durability of the produced cement and concrete (Ganjigatti et al, 2015; Khatib et al., 2012; Federico and Chidiac, 2009; Jani and Hogland, 2014). The review will be divided into three sections: the first section reviews the glass additive as aggregate, in the second section the partial replacement of cement with waste glass will be reviewed, while in the third section the addition of waste glass as fiber will be reviewed.

\section{Addition of Waste Glass as Aggregate}

A number of studies were carried out to investigate the properties of fresh and hardened self-compacted concrete when waste glass was added as aggregate. Tan and $\mathrm{Du}$ (2013) studied the properties of self-compacting glass concrete (SCGC) which consist of liquid crystal display (LCD) glass added to the cement to replace the aggregate in the following percentages: $(0,10,20,30) \%$ by applying standard tests such as slump flow, compressive and flexural strength on the produced concrete. Tan et al. observed that increasing replacement by LCD glass, decreases the compressive and flexural strengths. On the other hand, the slump flow increased with increasing glass replacement but reduced when glass percentage reaches $30 \%$.

Ali and Al-Tersawy (2012) studied the effect of using recycled glass waste as a partial replacement of fine aggregate by $(0,10,20,30,40,50) \%$, on the fresh such as slump flow and hardened properties of self-compacting concrete (SCC). Ali and Al-Tersawy used 18 concrete mixes that were produced with different cement contents $(350,400,450) \mathrm{kg} / \mathrm{m}^{3}$ at W/C ratio of 0.4 . Ali and Al-Tersawy had observed that the slump flow increased with the increase of recycled glass content. On the other hand, the compressive strength, splitting tensile strength and flexural strength were decreased with the increase in the recycled glass content (Idir et al., 
2009, 2010).

Gautam et al. (2012) studied the mechanical properties of self-compacted concrete with glass as a replacement of fine aggregate by $(10-40) \%$. Strength is found increase up to $20 \%$ replacement level. On the other hand, decrease in strength is observed at 30 to $40 \%$ replacement level of waste glass with fine aggregate. Also the optimum replacement level of waste glass as fine aggregate is $10 \%$ (Mageswari and Vidivelli, 2010).

Malik et al. (2013) studied the effect of using waste glass as a partial replacement of aggregate in self-compacted concrete on fresh properties, compressive strength and tensile by $(15,30,45) \%$. Malik, et al. showed that the slump flow increased with the increase of recycled glass. On the other hand, compressive strength and tensile strength of SCC decreased due to the weak bonding between the cement paste and the glass aggregate. In addition, the resistance to chloride ion penetrability and drying shrinkage were improved. The absorption and porosity to water for the glass were very low.

Ling, et al. (2012) studied the performance of self-compacted concrete as a partial replacement of fine aggregate by $(0,25,50,75,100) \%$ after exposure to four elevated temperatures of $(300,500,600,800){ }^{\circ} \mathrm{C}$. The influence of curing conditions on the high temperature performance of SCC were studied (Patel et al., 2012). Ling et al. conclude that when concrete is exposed to temperature, all the water cured specimens had higher residual strengths and mass losses, while the water porosity and absorption values were lower as compared to the corresponding air cured specimens (Mardani-Aghabaglou et al., 2015). Thereafter, Ling et al. (2013) studied the management and recycling of waste glass in concrete products.

De Castro and de Brito (2013) studied the mechanical properties of concrete such as durability made with glass as a replacement of natural aggregates (NA) by $(0,5,10,20) \%$ (Bajad et al. 2011. De Castro and de Brito found that the particle size strongly affects the workability of concrete due to the lower density of the glass aggregates. The mixes made with glass had a lighter fresh density than the standard concrete. Although there is a decrease in the compressive strength when the replacement rate increases. They found that, in most cases, the GA does not significantly alter the durability related properties of concrete.

\section{Addition of Waste Glass as a Partial Replacement of Cement}

A number of studies were carried out to investigate the fresh and hardened of self-compacted concrete by adding waste glass as a partial replacement of cement. Kim et al. (2014) studied the strength and durability properties of concrete with waste glass sludge (WGS) as a partial replacement of cement by $(0,10,20,30,40,50) \%$ under an environmental condition of freezing and thawing with the existence of de-icing salts (Matos and Sousa-Coutinho, 2012). Kim et al. showed that the compressive strengths of concrete with $(5-10) \%$ WGS are higher than the control mixture (Ergün, 2011). The resistance of concrete was improved to freezing and thawing cycles with and without de-icing salt (Degirmenci et al., 2011; Ling et al., 2011).

Tejaswi et al. (2015) studied the feasibility of using ground glass in self-compacting concrete (SCC) as a partial replacement for both the cement and fine aggregate on fresh and hardened concrete with replacing about $10 \%$ cement and 10\% sand (Saccani et al., 2010; Aly et al., 2012). Tejaswi et al. conclude that the strength was reduced with ground glass increase. The ground glass would require a small increase in water/powder ratio and the reduction in superplasticizer dosage in addition to saving landfill and reducing $\mathrm{CO}_{2}$ emissions by the use of less cement and sand (Vasudevan and Pillay, 2013).

Idir et al. (2011) studied the performance of concrete containing glass powder as partial replacement of Portland cement by $(0-40) \%$ glass powder. They have done tests such as; ultrasonic pulse velocity, compressive strength and absorption (Neithalath, 2011). The results indicated that the maximum strength of concrete occurs at around $10 \%$ glass powder. Beyond $10 \%$ glass powder, the strength of concrete reduces and is lower than that of the control concrete (Vijayakumar et al., 2013).

Chikhalikar and Tande (2012) observed that manufacturing process of cement produces large amount of carbon dioxide that it cause global warming and they oriented to replace a part of cement by $(0 \%, 10 \%, 20 \%, 30 \%, 40 \%)$ of glass to reduce the consumption of cement and the environmental pollution (Vandhiyan et al., 2013), also studied the workability and strength properties of concrete. Chikhalikar and Tande concluded that the $20 \%$ replacement of cement by waste glass powder will result in higher strengths, better workability, initial setting time and final setting time increased for concrete.

Soroushian (2012) studied the improvement in properties of construction materials by using waste glass as a powder by $(5,10,15) \%$ of cement in concrete. The compressive strength, split tensile strength, consistency and flexural strength are measured. The result showed glass powder improves the mechanical properties and is economical. 
Vaitkevičius et al. (2014) prepared glass powder of various types of recycled bottles that was used in ultra-high performance concrete (UHPC) as a partial replacement of cement by $(0-40) \%$. The result showed that adding glass lead to a decrease porosity of UHPC which is beneficial for mechanical and durability properties. Workability of concrete decreases when percentage of glass powder increases and bulk dry density of specimens decreases with the increase in percentage of glass powder.

Bhat and Rao (2014) studied the influence of glass powder on the properties of concrete and finding cost effective materials for increasing the strength of concrete structures with replacement of cement by waste glass powder by $(5,10,15,20) \%$ (Sangeetha et al., 2015). Bhat and Rao found that replacement $20 \%$ of cement by glass powder lead to increase compressive strength of $27 \%$. The slump was found to be 70 to $72 \mathrm{~mm}$. The water absorption decreases and with increase in glass content percentage. The use of waste glass in concrete produced economical concrete, reduced the disposal problem of waste glass and proved to be environmental friendly (Liu et al., 2015).

Altaf et al. (2013) studied the development of alternative binders to achieve better concrete by adding waste glass $(10,20,30,40) \%$ as a partial replacement of cement (Mobasher, 2011; Kaur, 2011) and tested that compressive and flexural strength up to 28 days of age. Jhala and Goliya found that after 28 days compressive strength of modified concrete is increased $17.11 \%$ for M30 grade and $12.51 \%$ for M40 grade of controlled concrete at the $20 \%$ replacement of cement by glass powder. Flexural strength is increased $12.23 \%$ for M30 grade and $7.11 \%$ for M40 grade of controlled concrete at the $20 \%$ replacement of cement by glass powder (Course and Theor, 2012).

Taha and Nounu (2009) studied the effect of partial replacement of cement by different pozzolanic materials such as glass on heat of hydration, setting time and compressive strength of concrete. Taha and Nounu conclude that adding glass by $(5,10,15,20) \%$ of cement achieved high compressive strength, low heat of hydration and increased initial and final setting time of concrete.

Meena (2012) studied the waste glass powder as pozzolanic material in concrete, the percentage of replacement cement by $(15,30) \%$ of glass powder on laboratory tests were normal consistency, compressive strength test and capillary absorption test were conducted (Jang, 2015). The result indicated that glass powder replacement produces higher strength.

Kumarappan (2013) studied the effect of glass powder as a partial replacement of cement in concrete. The global warming is caused by the emission of greenhouse gases such as $\mathrm{CO}_{2}$ to the atmosphere. $\mathrm{CO}_{2}$ contributes about $65 \%$ of global warming. The glass powder was partially replaced as $(10,20,30,40) \%$. Tests of compressive, tensile and flexural strength up to 60 days of age as well as durability test, workability test and alkalinity test were conducted. The results of replacement of glass powder in cement by $40 \%$ increase the split tensile strength by $4.4 \%$ and by $(20,30,40) \%$ increase the flexural strength by $(83.07,99.07,100) \%$.

Amen (2011) studied the replacement of cement by glass powder. Three mixes by $(5,10,15) \%$ of cement replaced by glass powder in weight and laboratory tests like plastic state tests, split tensile strength of concrete, compressive strength of concrete and flexural strength of concrete were conducted. The results show improvement in the split tensile strength and that the $10 \%$ replacement of cement by glass powder is the best proportion.

\section{Addition of Waste Glass as a Fiber}

A number of studies carried out to investigate the fresh and hardened of self-compacted concrete by adding waste plastic a fiber. Yu et al. (2014) studied the impact resistance and mechanical properties of self-compacting concrete reinforced with recycled glass fiber reinforced polymers (GFRP) by $(0.25,0.75,1.25) \%$ of fiber volume fractions (Chira et al. 2016; Kumar et al, 2015). The results showed that adding recycled glass fiber reinforced polymers improving the impact resistance (Chandramouli et al., 2010) and the mechanical properties of the reinforced self-compacting concrete with glass fiber reinforced polymers (Rabadiya and Vaniya, 2015; Chandramouli, 2010).

Mastali et al., 2016 studied the SCC made by usual ingredients such as cement, fine aggregate, coarse aggregate, water, mineral admixture fly ash (Yang et al., 2015; Tobbi, et al., 2012) and demolished concrete at various replacement percentage $(5,10,15,20) \%$ (Moustafa and El Gawady, 2016; Baena et al., 2016). To enhance the property of SCC made with the use of demolish concrete and fly ash, glass fiber has been added to the mix (Phani et al., 2015; Baena Muñoz et al., 2016). Glass fiber in various $(0.15,0.20,0.30) \%$ of Wt. of cement has been added in the mix which contain demolish concrete and gave the highest strength (Maranan et al., 2015). 


\section{Conclusion}

The review showed that waste glass can be used in concrete as a partial replacement of cement or aggregates. However, the particle size of the glass waste plays a vital role in the ASR destructive reaction and the performance of concrete. Increasing the percentage of waste glass aggregate reduces the maintenance of concrete Replacement of cement by glass powder lead to increase in compressive strength, the workability and the water absorption decreases, the resistance of concrete to freezing and thawing cycles were improved with and without de-icing salt. When used as a fine aggregate, the slump flow increased; the compressive strength, splitting tensile strength and flexural strength were decreased with the increase in the recycled glass content due to the weak bonding between the cement paste and the glass aggregate. The resistance to chloride ion penetrability and drying shrinkage was improved - the absorption and porosity of water for the glass was very low. In most studies the optimum percentage of waste glass (as aggregate or cement replacement) was $20 \%$, when they used waste glass in concrete to produce economical concrete that proved to be environmental friendly.

\section{Acknowledgments}

The authors would like to acknowledge the Prince Hussein Bin Abdullah II Library, AL Hussein Bin Talal University, Ma'an, Jordan and the Main Library, UAE University, Al Ain, UAE.

\section{References}

Ali, E. E., \& Al-Tersawy, S. H. (2012). Recycled glass as a partial replacement for fine aggregate in self compacting concrete. Construction and Building Materials, 35, 785-791.

Ali, M., Saidur, R., \& Hossain M. (2011). A review on emission analysis in cement industries. Renewable and Sustainable Energy Reviews, 15(5), 2252-2261.

Altaf, S. N., Asmat, K., M., Seemab, G. M., Aalan, K., M., \& Azim, K, F. (2013). Suitability of glass powder as a partial replaceemnt of cement in concrete. A project report submitted in partial fulfillment for Diploma In Civil Engineering. A.I.A.R. Kalsekar Polytechnic, New Panvel 410 206, Navi Mumbai.

Aly, M., et al. (2012). Effect of colloidal nano-silica on the mechanical and physical behaviour of waste-glass cement mortar. Materials \& Design, 33, 127-135.

Amen, D. K. (2011). Degree of hydration and strength development of low water-to-cement ratios in silica fume cement system. International Journal of Civil and Environment Engineering, 11(5), 10-16.

Baena, M. M., et al. (2016). Bond behaviour between recycled aggregate concrete and glass fibre reinforced polymer bars. Construction and Building Materials, 106, 449-460.

Baena, M., et al. (2016). Bond behaviour between recycled aggregate concrete and glass fibre reinforced polymer bars. Construction and Building Materials, 106, 449-460.

Bajad, M., Modhera, C., \& Desai, A. (2011). Effect of glass on strength of concrete subjected to sulphate attack. International journal of civil engineering research and development, 1(2), 01-13.

Bhat, V.V., \& Rao, N.B. (2014). Influence of glass powder on the properties of concrete. International Journal of Engineering Trrend and Technology (IJETT), 16(5), 196- 199.

Cassar, J., \& Camilleri, J. (2012). Utilisation of imploded glass in structural concrete. Construction and Building Materials, 29, 299-307.

Chandramouli, K., et al. (2010). Rapid chloride permeability test for durability studies on glass fibre reinforced concrete. ARPN Journal of engineering and applied sciences, 5(3), 67-71.

Chandramouli, K., et al. (2010). Strength properties of glass fiber concrete. ARPN journal of Engineering and Applied sciences, 5(4), 1-6.

Chikhalikar, S., \& Tande, S. (2012). An Experimental Investigation On Characteristics Properties of Fibre Reinforced Concrete Containing Waste Glass Powder as Pozzolona. in 37th Conference on Our World in Concrete and Structures, Singapore.

Chira, A., et al. (2016). Property improvements of alkali resistant glass fibres/epoxy composite with nanosilica for textile reinforced concrete applications. Materials \& Design, 89, 146-155.

Course, S.N. \& Theor, L. (2012). Scheme of studies \& examination. B. Tech. 1st Year (Semester-I) (Common for all branches) Credit Based Scheme wef. ETHICS, 1(50), p. 50.

De Castro, S., \& De Brito, J. (2013). Evaluation of the durability of concrete made with crushed glass aggregates. Journal of Cleaner Production, 41, 7-14. 
Degirmenci, N., Yilmaz, A., \& Cakir, O.A. (2011). Utilization of waste glass as sand replacement in cement mortar. Indian Journal of Engineering \& Materials Sciences, 18(4), 303-308.

Dhirendra, P., Yadav, R., \& Chandak R. (2012). Strength Characteristics of Pre Cast Concrete Blocks Incorporating Waste Glass Powder. ISCA J. Engineering Sci., 1(1), 68-70.

Ergün, A. (2011). Effects of the usage of diatomite and waste marble powder as partial replacement of cement on the mechanical properties of concrete. Construction and Building Materials, 25(2), 806-812.

Federico, L., \& Chidiac, S. (2009). Waste glass as a supplementary cementitious material in concrete-critical review of treatment methods. Cement and concrete composites, 31(8), 606-610.

Ganjigatti, M., Kashinath, B., \& Prakash, K. (2015). Effect of Replacement of Cement by Different Pozzolanic Materials on Heat of Hydration and Setting Time of Concrete. International Journal of Enviromental \& Argriculture Research, 1(4), 24-29.

Gautam, S., Srivastava, V., \& Agarwal, V. (2012). Use of glass wastes as fine aggregate in Concrete. J. Acad. Indus. Res., 1(6), 320-322.

Idir, R., Cyr, M., \& Tagnit-Hamou, A. (2009). Use of waste glass as powder and aggregate in cement-based materials. in Proc., SBEIDCO-1st Int. Conf. on Sustainable Built Environment Infrastructures in Developing Countries, Algeria.

Idir, R., Cyr, M., \& Tagnit-Hamou, A. (2010). Use of fine glass as ASR inhibitor in glass aggregate mortars. Construction and Building Materials, 24(7), 1309-1312.

Idir, R., Cyr, M., \& Tagnit-Hamou, A. (2011). Pozzolanic properties of fine and coarse color-mixed glass cullet. Cement and Concrete Composites, 33(1), 19-29.

Jang, H., et al., (2015). Properties of different particle size of recycled TFT-LCD waste glass powder as a cement concrete binder. International Journal of Precision Engineering and Manufacturing, 16(12), 2591-2597.

Jani, Y., \& Hogland, W. (2014). Waste glass in the production of cement and concrete-A review. Journal of Environmental Chemical Engineering, 2(3), 1767-1775.

Kaur, N. P. (2011). Active protection of corroded steel steel bar embeded in FRP wrpped concrete. Thapar University.

Khatib, J., et al. (2012). Glass powder utilisation in concrete production. European Journal of Applied Sciences, $4(4), 173-176$.

Khmiri, A., Samet, B., \& Chaabouni, M. (2012). Assessement of the waste glass powder pozzolanic activity by different methods. International Journal of Research and Reviews in Applied Sciences, 10(2), 322-328.

Kim, J., et al. (2014). Durability properties of a concrete with waste glass sludge exposed to freeze-and-thaw condition and de-icing salt. Construction and building materials, 66, 398-402.

Kumar, A., Kn, V. K., \& Anadinni, S. (2015). Suitability of Steel Slag and E-Sand in Glass Fiber Fly Ash Based Concrete.

Kumarappan, N. (2013). Partial Replacement Cement in Concrete Using Waste Glass. in International Journal of Engineering Research and Technology. ESRSA Publications.

Ling, T. C., Poon, C. S., \& Kou, S. C. (2011). Feasibility of using recycled glass in architectural cement mortars. Cement and Concrete Composites, 33(8), 848-854.

Ling, T. C., Poon, C. S., \& Kou, S. C. (2012). Influence of recycled glass content and curing conditions on the properties of self-compacting concrete after exposure to elevated temperatures. Cement and Concrete Composites, 34(2), 265-272.

Ling, T. C., Poon, C. S., \& Wong, H. W. (2013). Management and recycling of waste glass in concrete products: Current situations in Hong Kong. Resources, Conservation and Recycling, 70, 25-31.

Liu, M. (2011). Incorporating ground glass in self-compacting concrete. Construction and Building Materials, 25(2), 919-925.

Liu, S., Xie, G., \& Wang, S. (2015). Effect of curing temperature on hydration properties of waste glass powder in cement-based materials. Journal of Thermal Analysis and Calorimetry, 119(1), 47-55.

Mageswari, M. \& Vidivelli, B. (2010). The use of sheet glass powder as fine aggregate replacement in concrete. Open Civil Engineering Journal, 4, 65-71. 
Malik, M. I., et al. (2013). Study of concrete involving use of waste glass as partial replacement of fine aggregates. IOSR Journal of Engineering, 3(7), 08-13.

Maranan, G., et al. (2015). Evaluation of the flexural strength and serviceability of geopolymer concrete beams reinforced with glass-fibre-reinforced polymer (GFRP) bars. Engineering Structures, 101, 529-541.

Mardani-Aghabaglou, A., Tuyan, M., \& Ramyar, K. (2015). Mechanical and durability performance of concrete incorporating fine recycled concrete and glass aggregates. Materials and Structures, 48(8), 2629-2640.

Mastali, M., Dalvand, A., \& Sattarifard, A. (2016). The impact resistance and mechanical properties of reinforced self-compacting concrete with recycled glass fibre reinforced polymers. Journal of Cleaner Production.

Matos, A. M., \& Sousa-Coutinho, J. (2012). Durability of mortar using waste glass powder as cement replacement. Construction and Building Materials, 36, 205-215.

Meena, A. (2012). Comparative study of waste glass powder as pozzolanic material in concrete. Departemtn of Civil Engineering. A thesis submitted for the partial requirements for the bachelor of Science in Civil Engineeting. National Institute of Technology, Rourkela.

Mikulčić, H., Vujanović, M., \& Duić N. (2013). Reducing the CO2 emissions in croatian cement industry. Applied energy, 101, 41-48.

Mobasher, B. (2011). Mechanics of fiber and textile reinforced cement composites. 2011: CRC press.

Moustafa, A., \& El Gawady, M. A. (2016). Strain Rate Effect on Properties of Rubberized Concrete Confined with Glass Fiber-Reinforced Polymers. Journal of Composites for Construction, p. 04016014.

Neithalath, N. (2011). An overview of the benef its of using glass powder as a partial cement replacement material in concretes. Indian Concrete Journal, 85(2), 9-18.

Patel, D., Yadav, R., \& Chandak, R. (2012). Strength Characteristics of Cement Mortar Paste Containing Coarse and Fine Waste Glass Powder. International Journal of Engineering Sciences Research, 2, 683-686.

Phani, S.S., Sekhar, T.S., \& Rao, P.S. (2015). High Strength Self Compacting Concrete Beams Under Flexure. i-Manager's Journal on Structural Engineering, 4(2), p. 10.

Rabadiya, S., \& Vaniya, S. (2015). Effect of Recycled Aggregate with Glass Fiber on Concrete Properties. International Journal for Innovative Research in Science and Technology, 2(1), 257-265.

Saccani, A., \& Bignozzi, M. C. (2010). ASR expansion behavior of recycled glass fine aggregates in concrete. Cement and Concrete Research, 40(4), 531-536.

Sangeetha, R., Suji, D., \& Raghuraman, S. (2015). Comparative Study on Strength of Concrete by Partial Replacement of Fine Aggregate by Using M-Sand and Crushed Spent Fire Bricks. Journal of Civil and Construction Engineering, 1(2).

Soroushian, P. (2012). Strength and durability of recycled aggregate concrete containing milled glass as partial replacement for cement. Construction and Building Materials, 29, 368-377.

Taha, B., \& Nounu, G. (2009). Utilizing waste recycled glass as sand/cement replacement in concrete. Journal of Materials in Civil Engineering, 21(12), 709-721.

Tan, K. H., \& Du, H. (2013). Use of waste glass as sand in mortar: Part I-Fresh, mechanical and durability properties. Cement and Concrete Composites, 35(1), 109-117.

Tejaswi, S. S., et al. (2015). Experimental Investigation of Waste Glass Powder as Partial Replacement of Cement and Sand in Concrete. IUP Journal of Structural Engineering, 8(4), p. 14.

Tobbi, H., Farghaly, A. S., \& Benmokrane, B. (2012). Concrete columns reinforced longitudinally and transversally with glass fiber-reinforced polymer bars. ACI Structural Journal, 109(4), p. 551.

Vaitkevičius, V., Šerelis, E., \& Hilbig, H. (2014). The effect of glass powder on the microstructure of ultra high performance concrete. Construction and Building Materials, 68, 102-109.

Vandhiyan, R., Ramkumar, K., \& Ramya, R. (2013). Experimental study on replacement of cement by glass powder. in International Journal of Engineering Research and Technology, ESRSA Publications.

Vasudevan, G., \& Pillay, S. G. K. (2013). Performance of using waste glass powder in concrete as replacement of cement. American Journal of Engineering Research, 2(12), 175-181.

Vijayakumar, G., Vishaliny, M. H., \& Govindarajulu, D. (2013). Studies on glass powder as partial replacement 
of cement in concrete production. International Journal of Emerging Technology and Advanced Engineering, 3(2), 153-157.

Yang, W., et al. (2015). Effect of interfacial strength on the flexural behavior of glass fiber reinforced polymer (GFRP) reinforced concrete beam. Journal of Wuhan University of Technology-Mater. Sci. Ed., 30(5), 1001-1007.

Yu, R., et al. (2016). Development of Ultra-Lightweight Fibre Reinforced Concrete applying expanded waste glass. Journal of Cleaner Production, 112, 690-701.

\section{Copyrights}

Copyright for this article is retained by the author(s), with first publication rights granted to the journal.

This is an open-access article distributed under the terms and conditions of the Creative Commons Attribution license (http://creativecommons.org/licenses/by/3.0/). 